\title{
COMPOSITION CAPACITY OF SIDEWALK AFFORESTATION USING THREE DIFFERENT SIZED TREES
}

\author{
Jéssica Batista da Mata ${ }^{1}$, Daniela Sanson ${ }^{1}$, Alexandre Dal Forno Mastella² ${ }^{2}$ Rogério Bobrowski* \\ ${ }^{1}$ Universidade Estadual do Centro-Oeste, Programa de Pós-graduação em Ciências Florestais, Laboratório de Silvicultura Urbana, Irati, \\ Paraná, Brasil - e-mail jessicabdamata@gmail.com, danisczk@gmail.com \\ ${ }^{2}$ Universidade Federal do Paraná, Programa de Pós-graduação em Engenharia Florestal, Laboratório de Silvicultura, Curitiba, Paraná, Brasil \\ - e-mail alexandremastella@gmail.com \\ 3* Universidade Estadual do Centro-Oeste, Departamento de Engenharia Florestal, Laboratório de Silvicultura Urbana, Irati, Paraná, Brasil - \\ e-mail rogerio@unicentro.br
}

Received for publication: 30/06/2018 - Accepted for publication: 29/05/2019

\begin{abstract}
Resumo
Capacidade de composição da arborização de calçadas utilizando espécies de três portes diferentes. $\mathrm{O}$ planejamento da composição da arborização de calçadas é fundamental para compreender o desenvolvimento das árvores ao longo do tempo, bem como para permitir que as árvores forneçam seus inúmeros benefícios com qualidade. O objetivo deste trabalho foi avaliar o número de indivíduos de espécies arbóreas de pequeno, médio e grande porte ao longo de oito momentos de projeção de crescimento nas ruas da cidade de Irati -PR. Foram avaliadas diferentes ruas com e sem rede de energia, e ruas com calçadas maiores e menores que três metros, contabilizando-se o número de árvores cabíveis nos devidos espaços e calculando-se o incremento médio em área de copa de Lagerstroemia indica, Handroanthus albus and Paraptadenia rigida, ao longo de 5, 10, 15, 20, 25, 30, 35 e 40 anos de projeção do crescimento. Os dados foram transformados para atender ao critério normalidade e comparados pelo teste de Tukey à $5 \%$ de probabilidade, por meio de um delineamento em parcelas subdivididas. Houve diferença e interação significativa entre porte das espécies e tempo de projeção. A espécie de grande porte apresentou melhor incremento em área de copa ao longo dos anos, apesar do menor número de árvores cabíveis nas caçadas. Esse tipo de espécie é aconselhado para plantio desde que se leve em consideração a devida manutenção para que a árvore propicie benefícios máximos.

Palavras-chave: floresta urbana, silvicultura urbana, planejamento do plantio, gestão da floresta urbana.
\end{abstract}

\begin{abstract}
Planning the sidewalk afforestation composition is critical to understanding tree development over time, as well as enabling trees to deliver their many quality benefits. The objective of this work was to evaluate the number of small, medium and large-sized tree species during eight growth projection moments on the streets of Irati city-PR. Different streets with and without power grids and streets with sidewalks larger and smaller than three meters were evaluated by counting the number of suitable trees in the appropriate spaces and the average increase in crown area of Lagerstroemia indica, Handroanthus albus and Paraptadenia rigida, over 5, 10, 15, $20,25,30,35$ and 40 years of growth projection. Data was transformed to attend the normality criteria and compared by the Tukey test at $5 \%$ probability, using an experimental design in subdivided plots. There was a significant difference and interaction between species size and projection time. The large-sized species presented higher increase in crown area throughout the years, despite the smaller number of trees that could be planted. This kind of species is advised for planting as long as proper maintenance is considered for trees to provide maximum benefits.

Keywords: urban forest, urban forestry, planting planning, urban forest management.
\end{abstract}

\section{INTRODUCTION}

Changes in natural landscapes due to the continuous expansion of cities, including the addition of impermeable surfaces and consequent reduction of green areas, affect the biodiversity of urban ecosystems (HAASE et al., 2014) and give rise to a series of local and regional environmental challenges, especially from reduced soil permeability and increased runoff velocities that cause recurrent flooding (MILLER et al., 2014).

To overcome these problems, different typologies of urban forests are important spaces due to the many advantages they present (RAMÍREZ et al., 2014), as they provide a range of ecosystem services that contribute to the psychological health of people, the enhancement of tourist activities, the valuation of properties, the regulation of microclimate, the reduction of sound pressure and the reduction of runoff (MULLANEY et al., 2015; NESBITT et al., 2017).

However, such benefits are not fully achieved because species growth is generally limited by problems that affect access to water and nutrients for tree roots (MULLANEY et al., 2015). According to Rossetti et al. 
(2010), among the factors that negatively affect tree development in urban areas are the reduced size of beds, interference of pavement and improper construction, incompatibility with urban equipment such as power grids and lampposts, and root conflict with rainwater systems, gas lines and other utility pipelines. All of this makes urban trees more fragile, limiting their ability to reach full maturity when compared to individuals in natural habitats.

These constraining factors and problems should serve as background information for structuring a municipality's Urban Forest Mater Plan (UFMP). The UFMP is executed using technical-scientific criteria and should consider the characteristics of both the urban environment and biology of the species chosen for planting. This document aims to guide municipalities in planning, implementation and maintenance of trees in cities, along with the commitment of environmental agencies and the population, in order to provide harmony between vegetation and various urban infrastructures, since afforestation should always be an objective of prior planning (COPEL, 2009).

Urban forest planning should consider all biotic (trees and associated plants in flowerbeds) and abiotic (soil moisture and compaction, local microclimate characteristics, etc.) elements that make up the urban environment to ensure no future conflicts between tree development and human built infrastructure (MORAES; MACHADO, 2014). Thus, for urban afforestation to be effective in a municipality, trees planted on public sidewalks in front of homes and businesses should present adequate size and ecological characteristics (ROSSETTI et al., 2010).

However, for effective tree planning, the restrictions of the final tree dimensions and where they are to be placed must be considered, thus maximizing cost/benefits and/or reducing problems, as it is not always possible to modify sidewalks to receive tree elements.

In this context, the hypothesis of this work is that the composition capacity of sidewalk afforestation is regulated by the number of existing restrictions and the size of the tree species being used. Therefore, the objective was to evaluate the number of trees that could fit on sidewalks and the evolution of the crown area of small, medium and large tree species (Lagerstroemia indica, Handroanthus albus and Paraptadenia rigida) when subjected to different planting restrictions in the sidewalks of Irati city - PR.

\section{MATERIALS AND METHODS}

For planning scenarios of composition, this study got information about the structures of four streets from the municipality of Irati, which is located in the south-central region of Paraná state, between coordinates $25^{\circ} 27^{\prime} 56^{\prime \prime} \mathrm{S} ; 50^{\circ} 37^{\prime} 51^{\prime \prime} \mathrm{W}$ ) and within the Mixed Ombrophilous Forest phytogeographic region, inserted in the Atlantic Forest Biome.

To conduct the research, simulations with different sidewalk afforestation compositions (composition scenarios) were performed. To support these scenarios, data was first collected from four urban structure conditions: sidewalks with power grid, sidewalks without power grid, sidewalks smaller than three meters and sidewalks larger than three meters. For each urban structure condition, information was collected about sidewalk width and length, curb width, street width, presence and location of power grids and public infrastructures such as poles, bus stops, dumpsters, signs and traffic lights. Such data was collected from four block segments of the same street for each urban structure condition evaluated, to determine variations in the conditions of existence and provision of infrastructures.

For further support, planting recommendations were used, considering minimum safety distances from the corners, poles and curbs (Table 1), according to the size of each species considered (COPEL, 2009). This procedure was used to determine the number of seedlings that could be planted in each block segment.

Based on the variables evaluated and the safety distances restrictions, species that could fit in each sidewalk were selected to simulate the hypothetical composition scenarios. As a result, the species Lagerstroemia indica L. (extremosa), Handroanthus albus (Cham.) Mattos (ipê-amarelo-graúdo) and Parapiptadenia rigida (Benth.) Brenan. (angico-vermelho) were selected, which are small, medium and large sized, respectively, and adapted to the local urban conditions of Irati and the south-central region of Paraná state.

The minimum planting spaces were 4.0 meters for small size species, 6.0 meters for medium size and 8.0 meters for large size, provided that the safety distance restrictions were met (Table 1).

Table 1. Minimum safety distances (MSD) for each kind of urban infrastructure, in relation to tree species size ( $\mathrm{S}$ - small, $\mathrm{M}$ - medium, L - large).

Tabela 1. Distâncias mínimas de segurança (DMS) para cada tipo de infraestrutura urbana, em relação ao porte das espécies florestais ( $\mathrm{P}$ - pequeno, $\mathrm{M}$ - médio, $\mathrm{G}$ - grande). 


\begin{tabular}{l|c|cc}
\hline \multirow{2}{*}{ TYPE OF URBAN INFRASTRUCTURE } & \multicolumn{3}{|c}{ MSD (m) } \\
\cline { 2 - 4 } & $\mathbf{S}$ & \multicolumn{1}{|c}{ M } & L \\
\hline Corners & 5.0 & 5.0 & 5.0 \\
Public Lighting & 4.0 & 4.0 & 4.0 \\
Poles & 3.0 & 4.0 & 5.0 \\
Safety Equipment (Hydrants) & 1.0 & 2.0 & 3.0 \\
Underground installations (gas, water, sewage, etc.) & 1.0 & 1.0 & 1.0 \\
Inspection boxes (manholes, storm drains) & 2.0 & 2.0 & 3.0 \\
Garage entrance & 2.0 & 2.0 & 2.0 \\
Bus stop & 4.0 & 4.0 & 4.0 \\
Curb, pedestrian walkway edge & 1.0 & 2.0 & $1.5 \mathrm{R}^{*}$ \\
Transformers & 5.0 & 8.0 & 12.0 \\
\hline
\end{tabular}

Note: * Equals 1.5 times the radius at the base of the adult tree trunk.

Source: Adapted from Copel (2009)

In order to determine the composition of the scenarios over time, crown growth was estimated in eight different projected years $(5,10,15,20,25,30,35$ and 40 years) for the number of trees that could fit in each block segment. For this, information about the annual periodic increment (API) in crown area was obtained for each species, from a resampling inventory of trees on sidewalks of Curitiba (BOBROWSKI, 2011). In this research, an API of $0.32 \mathrm{~m}^{2}$ was observed for L. indica, $1.21 \mathrm{~m}^{2}$ for $H$. albus and $3.14 \mathrm{~m}^{2}$ for P. rigida. The initial seedling crown area of $0.19635 \mathrm{~m}^{2}$ or $0.50 \mathrm{~m}$ in diameter was adopted for a seedling with characteristics suitable for planting on sidewalks (minimum $2.10 \mathrm{~m}$ high and $1.80 \mathrm{~m}$ for the first bifurcation).

Given the lack of data about growth of urban tree crowns and the fact that tree growth can be influenced by several internal and external factors, the average API values could serve for this analysis, because they represent the average data of trees under free growing conditions, with or without pruning intervention or crown growth competition by interweaving. Since there are no crown growth models adjusted for the species used herein, the tree crown growth (CC) for each year was estimated from the API information, using the equation described below:

$$
C C_{i}=\frac{\pi d^{2}}{4}+(A P I \times i)
$$

where: $d$ is the average crown diameter of seedlings at planting, API is the annual periodic increment in crown diameter, $i$ is the year in which the crown area is projected.

The first statistical procedure evaluated whether there were differences between the numbers of suitable trees in each urban structure condition regarding size, by using a randomized block design where each block corresponded to a block segment in a given street.

The second statistical procedure evaluated whether there was difference between the crown areas by size class throughout the projected years. To evaluate if there was difference between the composition and use of different sizes of species, a 4x3 88 split-plot design was used with four blocks, each one corresponding to a block segment in a given street, with three tree sizes (small, medium and large) and each size evaluated in scenarios of growth projections for eight different years $(5,10,15,20,25,30,35$ and 40 years). The data was transformed by $\ln (\mathrm{x})$ to meet the homoscedasticity criterion evaluated by Bartlett's test. ANOVA was applied and when significant differences between treatments were found, the averages were compared using the Tukey test at a 5\% probability level.

\section{RESULTS}

Significant differences were found between tree size classes $(p<0.01)$ regarding the number of trees suitable for the sidewalks in all four urban structure conditions evaluated (Table 2). For the "sidewalk with power grid" condition, significant differences were observed between the blocks, which reflects the variability of the street conditions used as a model, in terms of the number and location of poles as structures that restrict tree planting.

The number of trees that could fit in the compositions of each urban structure condition was higher when small-sized species were used in all the urban structure conditions, showing significant differences between tree sizes considered (Table 3 ).

FLORESTA, Curitiba, PR, v. 50, n. 1, p. 983 - 990, jan/mar 2020. 
Regarding crown area of the trees, for the composition scenarios, significant differences and interaction $(p<0.01)$ were found between the factors "a" (species size) and "b" (projection time) in all urban structure conditions (Table 4). With the exception of the "sidewalk with power grid" condition, there were no significant differences $(p<0.01)$ between the blocks considered in the analysis of variance.

For all the years of the crown projection (Table 5), significant differences were found for the conditions "sidewalk with power grid" and "sidewalk without power grid" between the averages of small, medium and large size species $(p<0.05)$. In all the years, the large size species (Parapiptadenia rigida) stood out with the highest crown area averages.

The average crown areas at 40 years, by tree and size, represent realistic values for regional urban and environmental conditions, with approximately $4.0 \mathrm{~m}$ crown diameter and $13.0 \mathrm{~m}^{2}$ crown area for Lagerstroemia indica, $8.0 \mathrm{~m}$ crown diameter and $65.0 \mathrm{~m}^{2}$ crown area for Handroanthus albus and $12.0 \mathrm{~m}$ crown diameter and $125.0 \mathrm{~m}^{2}$ crown area for Parapiptadenia rigida. This strengthens and justifies using the average crown area increment values, even though there are no growth models available for the species contemplated in this research.

Table 2. Results of the analysis of variance for the number of trees per size class in each urban structure condition. Tabela 2. Resultado da análise de variância para o número de árvores por classe de porte, em cada condição da estrutura urbana.

\begin{tabular}{|c|c|c|c|c|c|}
\hline \multicolumn{3}{|c|}{ Sidewalk with power grid } & \multicolumn{3}{|c|}{ Sidewalk without power grid } \\
\hline FV & GL & QM & FV & GL & $\mathbf{Q M}$ \\
\hline Blocks & 3 & $23,417 * *$ & Blocks & 3 & 0,053 \\
\hline Size Class & 2 & $51,083^{* *}$ & Size Class & 2 & $67,000 * *$ \\
\hline Residue & 6 & 1,750 & Residue & 6 & 0,111 \\
\hline TOTAL & 11 & & TOTAL & 11 & \\
\hline \multicolumn{3}{|c|}{ Sidewalk less than $3.0 \mathrm{~m}$} & \multicolumn{3}{|c|}{ Sidewalk greater than $3.0 \mathrm{~m}$} \\
\hline FV & GL & QM & FV & GL & QM \\
\hline Blocks & 3 & 4,667 & Blocks & 3 & 3,889 \\
\hline Size Class & 2 & $21,000 * *$ & Size Class & 2 & $50,333 * *$ \\
\hline Residue & 6 & 1,000 & Residue & 6 & 0,556 \\
\hline TOTAL & 11 & & TOTAL & 11 & \\
\hline
\end{tabular}

Note: $* *$ Significant at $1 \%$ probability.

Table 3. Average number of trees per block of the urban structure condition, according to the restriction distances adopted.

Tabela 3. Número médio de árvores por bloco das condições da estrutura urbana, de acordo com as distâncias de restrição adotadas.

\begin{tabular}{lcccc}
\hline \multirow{2}{*}{ Size Class } & \multicolumn{4}{c}{ Types of the urban structure condition evaluated } \\
\cline { 2 - 5 } & $\begin{array}{c}\text { Sidewalk with } \\
\text { power grid }\end{array}$ & $\begin{array}{c}\text { Sidewalk without } \\
\text { power grid }\end{array}$ & $\begin{array}{c}\text { Sidewalk less } \\
\text { than } 3.0 \mathrm{~m}\end{array}$ & $\begin{array}{c}\text { Sidewalk greater } \\
\text { than } 3.0 \mathrm{~m}\end{array}$ \\
\hline Small & $13 \mathrm{a}$ & $19 \mathrm{a}$ & $12 \mathrm{a}$ & $16 \mathrm{a}$ \\
Medium & $8 \mathrm{~b}$ & $13 \mathrm{~b}$ & $9 \mathrm{ab}$ & $12 \mathrm{~b}$ \\
Large & $6 \mathrm{c}$ & $11 \mathrm{~b}$ & $7 \mathrm{~b}$ & $9 \mathrm{c}$ \\
\hline
\end{tabular}

Note: averages followed by the same letter in each column do not differ from each other, at $5 \%$ probability

Although the number of small trees is on average $50 \%$ higher than the number of large trees, these large trees could present a 79\% higher crown area. As for the medium-sized species, the number of suitable trees was on average $30 \%$ higher than the large species, and large species could present a $49 \%$ higher crown cover, from the fifth to the fortieth year of projection (Table 5).

Under the conditions where they were present, poles were structures that could potentially decrease the number of trees that could be planted on sidewalks. This resulted from the recommended protection restrictions that should be considered on both sides of this structure. On average, there was a reduction of five trees between the conditions with and without power grid, regardless of the size of species (Table 3). 
Table 4. Results of the analysis of variance for the distribution of crown area in each urban structure condition, in relation to two analysis factors, factor a (species size) and factor b (crown projection time). The blocks correspond to each street used as example in the scenarios.

Tabela 4. Resultados da análise de variância para a distribuição da área de copa em cada condição da estrutura urbana, em relação a dois fatores de análise, fator a (porte das espécies) and fator b (tempo de projeção das copas). Os blocos correspondem a cada rua utilizada como exemplo na elaboração dos cenários.

\begin{tabular}{|c|c|c|c|c|c|}
\hline \multicolumn{3}{|c|}{ Sidewalk with power grid } & \multicolumn{3}{|c|}{ Sidewalk without power grid } \\
\hline FV & GL & QM & FV & GL & QM \\
\hline Blocks & 3 & $3.106^{* *}$ & Blocks & 3 & 0.023 \\
\hline Factor a & 2 & $17.066^{* *}$ & Factor a & 2 & $22.956 * *$ \\
\hline Residue-a & 6 & 0.070 & Residue-a & 6 & 0.006 \\
\hline Factor b & 7 & $5.684 * *$ & Factor $\mathbf{b}$ & 7 & $5.696^{* *}$ \\
\hline Interaction a X b & 14 & $0.001 * *$ & Interaction $\mathrm{a} \mathrm{X} \mathrm{b}$ & 14 & $0.001 * *$ \\
\hline Residue-b & 63 & 0.000 & Residue-b & 63 & 0.000 \\
\hline TOTAL & 95 & & TOTAL & 95 & \\
\hline \multicolumn{3}{|c|}{ Sidewalk less than $3.0 \mathrm{~m}$} & \multicolumn{3}{|c|}{ Sidewalk greater than $3.0 \mathrm{~m}$} \\
\hline FV & GL & QM & FV & GL & QM \\
\hline Blocks & 3 & 0.433 & Blocks & 3 & 0.228 \\
\hline Factor a & 2 & $24.917 * *$ & Factor a & 2 & $22.510^{* *}$ \\
\hline Residue-a & 6 & 0.069 & Residue-a & 6 & 0.034 \\
\hline Factor b & 7 & $5.688 * *$ & Factor b & 7 & $5.684 * *$ \\
\hline Interaction a X b & 14 & $0.001 * *$ & Interaction $\mathrm{a} \mathrm{X} \mathrm{b}$ & 14 & $0.001 * *$ \\
\hline Residue-b & 63 & 0.000 & Residue-b & 63 & 0.000 \\
\hline TOTAL & 95 & & TOTAL & 95 & \\
\hline
\end{tabular}

Note: $* *$ Significant to $1 \%$ probability.

Table 5. Average crown area projection time (years) for the total number of small, medium and large size trees $(\mathrm{N})$ in each street (block) and in relation to the different urban structure conditions.

Tabela 5. Área de copa média, em diferentes anos de projeção, para o número total de árvores (N) de pequeno, médio and grande porte cabíveis em cada rua (bloco) and em relação a diferentes condições da estrutura urbana.

\begin{tabular}{|c|c|c|c|c|c|c|c|c|c|}
\hline \multirow{2}{*}{ Size Class } & \multirow{2}{*}{$\mathbf{N}$} & \multicolumn{8}{|c|}{ Crown area projection time, in years } \\
\hline & & 5 & 10 & 15 & 20 & 25 & 30 & 35 & 40 \\
\hline \multicolumn{10}{|c|}{ Sidewalk with power grid } \\
\hline Small & 13 & $23.4 \mathrm{cH}$ & $44.2 \mathrm{cG}$ & $65.0 \mathrm{cF}$ & $85.8 \mathrm{cE}$ & $106.6 \mathrm{cD}$ & $127.4 \mathrm{cC}$ & $148.2 \mathrm{cB}$ & $169.0 \mathrm{cA}$ \\
\hline Medium & 8 & $51.5 \mathrm{bH}$ & $101.4 \mathrm{bG}$ & $151.4 \mathrm{bF}$ & $201.3 \mathrm{bE}$ & $251.2 \mathrm{bD}$ & $301.1 \mathrm{bC}$ & $351.0 \mathrm{bB}$ & $400.9 \mathrm{bA}$ \\
\hline Large & 6 & $95.4 \mathrm{aH}$ & $\begin{array}{c}189.66 \\
\mathrm{aG}\end{array}$ & $283.8 \mathrm{aF}$ & $378.0 \mathrm{aE}$ & $472.2 \mathrm{aD}$ & $566.4 \mathrm{aC}$ & $660.6 \mathrm{aB}$ & $754.8 \mathrm{aA}$ \\
\hline \multicolumn{10}{|c|}{ Sidewalk without power grid } \\
\hline Small & 19 & $33.7 \mathrm{cH}$ & $63.7 \mathrm{cG}$ & $93.7 \mathrm{cF}$ & $123.7 \mathrm{cE}$ & $153.7 \mathrm{cD}$ & $183.7 \mathrm{cC}$ & $213.7 \mathrm{cB}$ & $243.7 \mathrm{cA}$ \\
\hline Medium & 13 & $82.8 \mathrm{bH}$ & $162.9 \mathrm{bG}$ & $\begin{array}{c}243.1 \\
b F\end{array}$ & $323.3 \mathrm{bE}$ & $403.4 \mathrm{bD}$ & $483.6 \mathrm{bC}$ & $563.7 \mathrm{bB}$ & $643.9 \mathrm{bA}$ \\
\hline Large & 11 & $170.9 \mathrm{aH}$ & $339.7 \mathrm{aG}$ & $508.4 \mathrm{aF}$ & $677.2 \mathrm{aE}$ & $846.0 \mathrm{aD}$ & $\begin{array}{c}1014.8 \\
\mathrm{aC}\end{array}$ & $1183.5 \mathrm{aB}$ & $1352.3 \mathrm{aA}$ \\
\hline \multicolumn{10}{|c|}{ Sidewalk less than $3.0 \mathrm{~m}$} \\
\hline Small & 12 & $20.7 \mathrm{cH}$ & $39.1 \mathrm{cG}$ & $57.5 \mathrm{cF}$ & $75.9 \mathrm{cE}$ & $94.3 \mathrm{cD}$ & $112.7 \mathrm{cC}$ & $131.1 \mathrm{cB}$ & $149.5 \mathrm{cA}$ \\
\hline Medium & 9 & $53.1 \mathrm{bH}$ & $104.5 \mathrm{bG}$ & $155.9 \mathrm{bF}$ & $207.4 \mathrm{bE}$ & $258.8 \mathrm{bD}$ & $310.2 \mathrm{bC}$ & $361.6 \mathrm{bB}$ & $413.1 \mathrm{bA}$ \\
\hline Large & 7 & $111.3 \mathrm{aH}$ & $221.2 \mathrm{aG}$ & $331.1 \mathrm{aF}$ & $441.0 \mathrm{aE}$ & $550.9 \mathrm{aD}$ & $660.8 \mathrm{aC}$ & $770.7 \mathrm{aB}$ & $880.6 \mathrm{aA}$ \\
\hline \multicolumn{10}{|c|}{ Sidewalk greater than $3.0 \mathrm{~m}$} \\
\hline Small & 16 & $28.7 \mathrm{cH}$ & $54.3 \mathrm{cG}$ & $79.9 \mathrm{cF}$ & $105.5 \mathrm{cE}$ & $131.1 \mathrm{cD}$ & $156.7 \mathrm{cC}$ & $182.3 \mathrm{cB}$ & $207.9 \mathrm{cA}$ \\
\hline Medium & 12 & $71.8 \mathrm{bH}$ & $141.4 \mathrm{bG}$ & $211.0 \mathrm{bF}$ & $280.6 \mathrm{bE}$ & $350.1 \mathrm{bD}$ & $419.7 \mathrm{bC}$ & $489.3 \mathrm{bB}$ & $558.9 \mathrm{bA}$ \\
\hline Large & 9 & $143.1 \mathrm{aH}$ & $284.4 \mathrm{aG}$ & $425.7 \mathrm{aF}$ & $567.0 \mathrm{aE}$ & $708.3 \mathrm{aD}$ & $849.6 \mathrm{aC}$ & $990.9 \mathrm{aB}$ & $1132.2 \mathrm{aA}$ \\
\hline
\end{tabular}

Note: averages followed by the same lowercase letter in each column do not differ significantly from each other at $5 \%$ probability; Averages followed by the same capital letter, in each line, also do not differ significantly from each other at $5 \%$ probability. 


\section{DISCUSSION}

For some of the urban structure conditions, the differences between blocks, which correspond to the streets used as models, reflect the variability of the presence and type of urban structure that imposes higher or lower protection distance, depending on the size of the species used. According to the urban structure condition, these restrictions delimited the number of trees and amount of crown area over the years.

The difference observed within the first five years between the three tree sizes is important when considering sidewalk trees as potential urban environmental mitigation structures. Even with half the number of trees, the large-sized species could represent the largest crown projection in all scenarios of post-planting years, which is a positive point regarding concerns about environmental benefits, as the crown is the part of the tree that best expresses such benefits (BOBROWSKI; BIONDI, 2012). However, environmental variations in the city that affect plant stress may influence the results by conditioning adaptability and tree growth (CALFAPIETRA et al., 2015). As for the results, better estimates could be made using crown area growth equations, which may express growth particularities and variations more adequately in light of urban environmental conditions.

The observations of this research are consistent with those of Almeida and Rondon Neto (2010), who conducted an inventory in three cities from Mato Grosso do Sul. The authors observed a larger number of trees planted in sidewalks without power grids, as an attempt to reduce conflicts with urban structures. This was also observed in other Brazilian cities where inventories of trees on sidewalks contemplated urban structure variables and the interactions with trees (LAZZARI et al., 2015; CASTRO et al., 2016).

The similarity between the blocks in the "sidewalks without power grid" condition can be justified by the reduced presence of urban infrastructures, which reduces the protection restrictions to be considered in these streets and increases the possibility of planting and growing trees. This result indicates that streets with low constraints allow greater planning possibilities, fitting small, medium or large-sized trees into sidewalks, depending on variables such as sidewalk width, street width and the existence of front indentation of buildings. For Albertin et al. (2014), choosing suitable species should be based on the location and quantity of different urban structures that may come into conflict with the trees, as well as the land occupation characteristics as distance, indents and street widths.

Regarding the conditions "sidewalk greater than $3.0 \mathrm{~m}$ " and "sidewalk smaller than $3.0 \mathrm{~m}$ ", the distinctions between number of trees and crown projection area may not be better or worse, but can express only insertion limitations for trees and some urban infrastructures that demands protection distances.

The results presented in Table 5 show that in the absence of restriction associated with the power grids, the large-sized composition stands out in terms of crown projection and may enhance benefits from early years. In this case, even medium-sized species are more preferable to small-sized ones, given the spatial limitation for planting large trees.

Large tree species have higher increases in area and crown projection and, consequently, may provide better benefits when compared to small and medium size species. In a study about the change of the cost-benefit rate of trees regarding size in the city of Modesto, California, McPherson (2003) stated that it is possible to estimate how much benefits increase as tree size class increases, that is, large trees generate a higher cost benefit. Martini et al., (2017) found that on the streets of Curitiba where the sidewalks were covered by the large-sized species Tipuana tipu, the regulation of microclimate variables was better compared to sidewalks where the small-sized and thin crown species Handroanthus crysotrichus were planted. This is due to the greater temperature reduction and higher moisture retention in the composition with T. tipu in summer and its similarity to unpopulated streets in the winter, as it is a deciduous species.

However, guidelines done by electric power companies, recommend that large trees must not be planted on sidewalks with power grids. On the other hand, Milano and Dalcin (2000) state that larger trees on sidewalks can be guided way from power grids through proper pruning. For Oliveira et al. (2014), trees exceeding 10 meters tall comply with public infrastructures, as they are able to surpass the lampposts and electrical grid structures. However, opting for large trees under the power grid requires the public/popular will or decision given the characteristics of each city or place, which should be based on data regarding the relationship between the costs of power grids maintenance, type of power grid, and the monetary value added from the environmental, economic and social benefits offered by trees.

In a study conducted in the city of Portland, Donovan and Prestemon (2012) found that large trees are associated with reduced crime compared to small trees, as small trees tend to obstruct the street landscape and reduce the visibility for pedestrians and drivers.

On the other hand, medium-sized trees conflict more with aerial power grids, because the average height of this structure coincides with the crown of these trees. Thus, medium-sized trees do not exceed the height of the medium-voltage lines, making it necessary to prune these trees more frequently when they are near the power grids, which cause trees to lose their form and natural architecture (MILANO; DALCIN, 2000; BOBROWSKI; 
BIONDI, 2016). Therefore, the São Paulo urban forest manual (SÃO PAULO, 2015) recommends using small or large species when there is a conventional or compact aerial power grid.

\section{CONCLUSIONS}

- The number of suitable trees and crown area varied according to the urban structure condition evaluated, which determined distinct planting restrictions;

- The less restricted sidewalks could made it possible to plant more trees and to express a larger total crown area;

- In all the urban structure conditions evaluated and throughout the projection time, the large species showed larger crown area, despite the smaller number of trees that could be planted.

\section{REFERENCES}

ALBERTIN, R. M.; ANGELIS B. L. D. de; SILVA, F. F.; ANGEOLETTO, F. H. S.; RÊGO, N.; SANTIL, F. Analysis of street tree and urban infrastructure in Joubert de Carvalho street, Maringá-Paraná, Brazil. Electronic Journal of Management, Education and Environmental Technology (REGET), v. 18, n. 3, p. 1223-1236, 2014.

ALMEIDA, D. N.; RONDON NETO, R. M. Análise da arborização urbana de três cidades da região norte do Estado de Mato Grosso. Acta Amazônica, v. 40, n. 4, p. 647-656, 2010.

BOBROWSKI, R. Estrutura e dinâmica da arborização de ruas de Curitiba, Paraná, no período 1984 - 2010. 144 f. 2011. Dissertação (Mestrado em Engenharia Florestal) - Setor de Ciências Agrárias, Universidade Federal do Paraná, Curitiba.

BOBROWSKI, R.; BIONDI, D. Distribuição e dinâmica da área de copa na arborização de ruas de Curitiba, Paraná, Brasil, no período de 1984-2010. Árvore, v. 36, n. 4, p. 625-635, 2012.

BOBROWSKI, R; BIONDI, D. Percepção e preferência popular por atributos estéticos e ecológicos na composição da arborização de ruas. Floresta, v. 46, n. 1, p. 123, 2016.

CALFAPIETRA, C.; PEÑUELAS, J.; NIINEMETS, U. Urban plant physiology: adaptation-mitigation strategies under permanent stress. Trends in Plant Science, v. 2, n. 25, p. 72-75, 2015.

CASTRO, H. S.; DIAS, T. C. A. C.; AMANAJÁS, V. V. V. As geotecnologias como ferramenta para o diagnóstico da arborização urbana: o caso de Macapá, Amapá. RaeGa - o espaço geográfico em análise, v. 38, n. 1, p. 146$168,2016$.

COPEL - COMPANHIA PARANAENSE DE ENERGIA ELÉTRICA. Arborização de Vias Públicas: Guia para os Municípios. Curitiba, 2009.

DONOVAN, G. H.; PRESTEMON, J. P. The effect of trees on crime in Portland, Oregon. Environment and Behavior, v. 44, n. 1, p. 3-30, 2012.

HAASE, D.; LARONDELLE, N.; ANDERSSON, E.; ARTMANN, M.; BORGSTRÖM, S.; BREUSTE, J.; GOMEZ-BAGGETHUN, E.; GREN, A.; HAMSTEAD, Z.; HANSEN, R.; KABISCH, N.; KREMER, P.; LANGEMEYER, J.; RALL, E. L.; MCPHEARSON, T.; PAULEIT, S.; QURESHI, S.; SCHWARZ, N.; VOIGT, A.; WURSTER, D.; ELMQVIST. T. A quantitative review of urban ecosystem service assessments: concepts, models, and implementation. AMBIO, v. 43, n. 4, p. 413-433, 2014.

LAZZARI, L.; GEORGIN, J.; CAMPONOGARA, A.; MAGGIONI, J. H.; OLIVEIRA, G. A.; ROSA, A. L. D. Diagnóstico da arborização urbana da rua Arthur Milani na cidade de Frederico Westphalen-RS. Revista Eletrônica em Gestão, Educação e Tecnologia Ambiental, v. 19, n. 3, p. 13-24, 2015.

MARTINI, A.; BIONDI, D.; BATISTA, A. C. The microclimate of different landscape arrangements in street trees of Curitiba-PR State. Ciência Florestal, v. 27, n. 4, p. 1257-1268, 2017.

MCPHERSON, E. G. A benefit-cost analysis of ten tree species in Modesto, California, USA. Journal of Arboriculture. v. 29, n. 1, p. 1-8, 2003.

MILANO, M.S; DALCIN, E. Arborização de vias públicas. Rio de Janeiro: Light, 2000. 226p. 
MILLER, J. D.; KIM, H.; KJELDSEN, T. R.; PACKMAN, J.; GREBBY, S.; DEARDEN, R. Assessing the impact of urbanization on storm runoff in a peri-urban catchment using historical change in impervious cover. Journal of Hydrology, v. 515, n. 1, p. 59-70, 2014.

MORAES, L.A., MACHADO, R.R.B. A arborização urbana do município de Timon/MA: inventário, diversidade e diagnóstico quali-quantitativo. Revista da Sociedade Brasileira de Arborização Urbana, v. 9, n. 4, p. 80-98, 2014.

MULLANEY, J.; LUCKE, T.; TRUEMAN, S. J. A review of benefits and challenges in growing street trees in paved urban environments. Landscape and Urban Planning, v. 134, n.1, p. 157-166, 2015.

NESBITT, L.; HOTTEB, N.; BARRONA, S.; COWANC, J.; SHEPPARDA, S. R. J. The social and economic value of cultural ecosystem services provided by urban forests in North America: A review and suggestions for future research. Urban Forestry \& Urban Greening, v. 25, n.1, p. 103-111, 2017.

OLIVEIRA, A. F; PEREIRA, J. A. A; COELHO, S. J; PEREIRA, G. A. Uso da classificação da vegetação no manejo integrado entre árvores e redes de distribuição de energia elétrica. Revista da Sociedade Brasileira de Arborização Urbana, v. 9, n. 2, p. 168-183, 2014.

RAMÍREZ, D. A. H.; PELÁEZ, J. D. L.; RENDÓN, M. R.; VEGA, N. W. O.; LONDOÑO, G. C.; RICARDO, R. E.; BRAVO, A. U. Evaluation of nutritional requirements in nurseries of tropical species used in urban greening. Revista EIA, v. 11, n. 21, p. 39-52, 2014.

ROSSETTI, A. I. N.; PELlEGRINO, P. R. M.; TAVARES, A. R. As árvores e suas interfaces no ambiente urbano. Revista da Sociedade Brasileira de Arborização Urbana, v. 5, n. 1, p. 1-24, 2010.

SÃO PAUlO. SECRETARIA MUNICIPAL DO VERDE E DO MEIO AMBIENTE. Manual Técnico de São $\begin{array}{llll}\text { Arborização } & \text { Urbana. } & \text { Disponível em: }\end{array}$ <http://www.prefeitura.sp.gov.br/cidade/secretarias/upload/meio_ambiente/MARBOURB.pdf>. Acesso em 26 jan. 2018. 